\title{
REFRANES Y GÉNERO ${ }^{1}$
}

\author{
ISABEL ECHEVARRÍA ISUSQUIZA²
}

Universidad del País Vasco / Euskal Herriko Unibertsitatea

\section{Resumen}

La riqueza heterogénea del Vocabulario de Correas invita a realizar una aproximación amplia a la paremiología desde el género, más allá de la misoginia del refranero, sin duda uno de sus rasgos temáticos sobresalientes, pero que no es el tema de este trabajo. Sí tratamos de contemplar cómo las figuras femeninas aparecen representadas por su propia voz, para observar cómo hablan en los refranes, escenificando el estereotipo de sus conductas y palabras. Y de "las mujeres de la fraseología" llegaremos a "la fraseología de mujeres", es decir, aquella que les es propia y lleva su huella, porque forma parte de su educación a través de la transmisión oral de saberes prácticos y de consejos morales.

Palabras clave: Correas, Vocabulario de refranes y frases proverbiales género, paremiología, voz femenina en el refranero, el habla de las mujeres.

\begin{abstract}
The aim of this article is to study Gonzalo Correas's Vocabulario de refranes y frases proverbiales from the perspective of gender, since its heterogeneous richness allows us to analyze it beyond the proverbs' misogyny. By examining those proverbs spoken in female voice we can gather information about the stereotypes regarding female conduct and speech. In turn, from this female phraseology one can indentify and trace marks of female speech influenced by their upbringing and by oral transmission, practical know-how and moral sayings.
\end{abstract}

Key words: Correas, Vocabulario de refranes y frases proverbiales, gender, proverbs, female's voice in proverbs's collections, female speech.

\footnotetext{
${ }^{1}$ Una versión más amplia de la última parte de esta investigación (§ 4. Fraseología de mujeres), fue presentada en el Congreso Internacional de Fraseología y Paremiología celebrado en Santiago y Lugo (IX2006) y se ha publicado con el título "Refranes y frases de mujeres en el Vocabulario de Correas" (Echevarría Isusquiza, 2007), trabajo al que remitimos para una ejemplificación más completa de este apartado.

${ }^{2}$ Universidad del país Vasco. Correo: isabel.echevarria@ehu.es. Recibido: 28-11-2010. Aceptado: 27-022011.
} 


\section{EL VOCABULARIO DE CORREAS, LOS REFRANES, LA LITERATURA Y}

\section{LA LENGUA}

Con el Vocabulario de refranes y frases proverbiales de Gonzalo Correas (1627) ${ }^{3}$, culmina la tradición paremiográfica que arranca en Castilla en los siglos XIII y XIV, cuando ven la luz las primeras colecciones de refranes. Pero el Vocabulario rebosa interés más allá de la paremiología, por la riqueza y heterogeneidad de los materiales que reúne, casi 25.000 refranes, frases proverbiales y expresiones muy diversas. Los refranes, unos 18.000, ocupan la $1^{\mathrm{a}}$ parte de la colección, que incorpora lo esencial, si no la totalidad de la materia paremiológica recogida por sus predecesores ${ }^{4}$. Por ello, cabe considerar que los refranes del Vocabulario comprenden un período entre el XIV y la época de compilación del repertorio (primer cuarto del XVII) 5 .

La aportación original de la obra es muy notable, pues alrededor de 8.000 paremias son fruto de la tarea de inmersión en la tradición popular oral, que ocupó a Correas entre 1608 y 1625. Por estas fechas, que coinciden con los últimos años de su vida, es fama que aprovechaba los días de mercado para ponerse en un sillón en la cabeza del puente de Salamanca a comprar refranes nuevos a los campesinos que llegaban a la ciudad. Correas había adoptado las extravagantes ideas del Dr. López Madera, de acuerdo con las cuales el castellano existía ya en el momento de la formación del latín. Esta posición -según certeramente observa Combet (1971: 172)- le comprometía tal vez más aún a profundizar en el conocimiento de su propia lengua, que él situaba en la jerarquía lingüística en segundo lugar, inmediatamente después del griego. Si el Arte de la lengua castellana ${ }^{6}$ y el Vocabulario de refranes deben quizá su nacimiento a estas tesis insostenibles, ambas obras sobrepasan su destino original (la gramática una y la paremiología la otra) para abocar a una zona aún inexplorada en su época, lo que llamamos folklore (Combet, 1971: 173 y ss.).

\footnotetext{
${ }^{3}$ Como se sabe, la obra no fue publicada en vida del autor; El "manuscripto en papelón" del Vocabulario -se supone que el borrador estaría terminado hacia 1627-, legado por el autor al Colegio Trilingüe, quedó olvidado en Salamanca y se consideró perdido durante mucho tiempo. La edición que utilizamos está basada en la edición crítica de Combet, con una transcripción modernizada para una mayor manejabilidad. En palabras del editor R. James (2000: X), se trata de "un texto doblemente revisado", que puede utilizarse "en confianza, como versión fidedigna, aunque modernizada, de la colección del maestro Correas".

${ }^{4} \mathrm{Y}$ así lo declara el título: Vokabulario de Refranes, i Frases Proverbiales $i$ otras formulas komunes de la lengua kastellana, en ke van todos los impresos antes, i otra gran kopia que xunto el Maestro Gonzalo Korreas, [...] (apud Combet, 1971: 168). Se refiere a Pedro Vallés (1549), Hernán Núñez (1555) y Juan de Mal Lara (1568), en sus refraneros respectivos; con otras fuentes secundarias, como el Diccionario de vocablos castellanos de Sánchez de la Ballesta (1587), etc.

${ }^{5}$ Además del "Prólogo de la edición de 1967" (Combet, [1967] 2000), debe verse el estudio fundamental de L. Combet (1971), especialmente, por lo que se refiere a Correas, la $2^{\mathrm{a}}$ parte, cap. IV, pp. 167-177 ("Gonzalo Correas et le Vocabulario de refranes"), de donde tomamos las observaciones anteriores. Combet consagra también a Correas el análisis de la tercera parte de sus Recherches, y los Apéndices I y II (1971: 179-288, 387-388, 389-446).
}

${ }^{6}$ El Arte de la lengua Española Castellana, preparada para la impresión en 1625, pero no publicada en vida, es la otra gran obra del maestro Correas. 
Correas no se limitó a reunir aquellas formulaciones que tenían carácter preceptivo (sentencias, adagios, máximas, aforismos, etc.) sino que acogió, en general, todo lo que le pareció notable en la comunicación cotidiana: estereotipos y clichés, giros curiosos, chistes, adivinanzas, pullas, juramentos, maldiciones, etc., así como una infinidad de coplas, estribillos, y canciones. Y presenta deliberadamente esta extensa colección de documentos verbales con las deformaciones fonéticas, semánticas o sintácticas propias de su vida exclusivamente oral ${ }^{7}$. Las glosas del Vocabulario se atienen a aclarar las dificultades interpretativas, con explicaciones que Correas toma de la herencia popular, que es la que le proporciona sus mejores textos (Combet, íbidem).

Una muestra de los géneros populares tradicionales que podemos hallar en el Vocabulario es el "coloquio con sorda":

¿Cómo estáis, casada? -Barriendo y regando cada mañana. -¿Cómo estáis, os digo?- A la aceña fue mi marido. - ¿Vos trasoídes? - Una hanega y dos celemines. - ¿Sois sorda? - Buena y gorda. - ¡Válate el diablo con la mujer! -Dios vaya con él. (VR, 109)

Los que Correas llama "juegos de conversación”, como estos:

¡Ay! -¿Qué tenéis, amor? -Mal de corazón. -¿Quién os lo causó? -El de lo verde. O la de lo azul; u otra cualquiera color que quieran decir. (VR, 114)

Los mosquitos, ¿tienen ojos? -Sí, mis ojos. -¿Pican bien? -Sí, mi bien. - ¿Pican en la palma? -Sí, mi alma. - ¿Y en la oliva? -Sí, mi vida. -¿Quiéreste casar conmigo? -Sí, que lo digo. - ¿Quiéresmele dar? -Ni llegar. (VR, 473)

Las muchas canciones y versos infantiles, algunos de los cuales se acompañan de explicaciones acerca de su contexto pragmático:

Sal, sol, solito, / y estáte aquí un poquito; / por hoy y mañana, / y por toda la semana. / Aquí vienen las monjas / cargadas de toronjas; / no pueden pasar / por el río de la mar; / pasa uno, pasan dos, / pasa la madre de Dios, / con su caballito blanco / que relumbra todo el campo; / aquí viene Periquito / con un cantarito / de agua caliente, / que me espanta a mí y a toda la gente. (VR, 719)

Sal, lagartija, que matan a tu hija; sal al sol, sal, que la llevan a quemar.

Dicen esto los chiquillos, buscando lagartijas entre las piedras. (VR, 718)

Milano, toma este diente y damo otro sano.

Dicen esto los muchachos arrojando el diente que mudan sobre un tejado, y acomódase a otras cosas que truecan por mejores. $(\mathrm{VR}, 525)$

Mentís. -No es deshonra, mas es palavra de ruin persona. -Tal como vos. -Bésame el culo y andá con Dios.

Esto responden los muchachos cuando se desmienten, con que se descargan bastantemente; y fuera bueno que a veces bastara entre hombres. (VR, 517)

\footnotetext{
${ }^{7}$ Vid. R. Jammes ([1967] 2000). Se verán después algunos ejemplos, pero vaya aquí una muestra: “Irés por lana, y vernés tresquilada", de donde el propio Correas comenta: "A lo rústico, por "iréis" y "vernéis" (VR, 402).

${ }^{8}$ Los refranes se citan en cursiva para distinguirlos de las glosas que acompañan a algunos. Aprovecho asimismo para advertir que la ejemplificación que este trabajo ofrece es abundante pero no exhaustiva; sin embargo, el examen del corpus en que este estudio se basa sí es exhaustivo y completo.
} 
Correas no deja de advertir la conexión entre literatura y refranes. Así, de Madre la mi madre, guardas me ponéis; que si yo no me guardo, mal me guardaréis, comenta que "Es Refrán que salió de cantar (VR, 481)"9. Y de Pésame de vos, el conde, señala que "Quedó en refrán del cantar viejo $(\mathrm{VR}, 636)^{10}$; como el siguiente estribillo convertido en refrán:

¡Para la muerte que a Dios debo, de perejil está el mortero!

Contra los que se espantan y hacen caramillo de cosas de nonada. Es estribillo de aquel cantar: “Comadres, las mis comadres, / yo tengo dos criadas / muy bellacas y muy malas; / por estarse arrellanadas / nunca limpian el majadero; / ipara la muerte que a Dios debo, / de perejil está el mortero!" (VR, 622)

En palabras de Menéndez Pidal (1982: 35), “los romances estaban tan presentes en la memoria de todos, que sus versos fluían a cada paso, en la conversación ordinaria, como elementos fraseológicos del idioma". Y aunque son incontables los relatos propuestos como explicación de los dichos, sin embargo la opinión de Correas es que no hay necesariamente prelación entre literatura y fraseología, pues "De cuentos fingidos se hacen refranes, y de refranes se fingen cuentos":

Buen provecho te hagan los salvadillos.

De cuentos fingidos se hacen refranes, y de refranes se fingen cuentos; el déste es: que la zorra tenía un vecino que muy a menudo daba salvados a un cebón; ella, con hambre, tenía envidia de aquel regalo; mas consolóse viéndole matar por san Martín, diciendo: "Buen provecho te hagan los salvadillos". (VR, 132)

No escupiré, aunque me ahogue.

Quería escupir la mujer y dijo al marido que la diese lugar; dijo él: "No escupáis, que me iré de la cama"; ella le detuvo diciendo: "No escupiré, aunque me ahogue". Fíngese el cuento para para refrán, y el refrán para el cuento. (VR, 567)

Dicho de otro modo, “... de rrefranes se an fundado muchos cantares, i al contrario de cantares an quedado muchos rrefranes, como son todos los estribillos de villanzicos i cantarzillos viexos"11. Por esta vía, M. Frenk (1961) ha constatado que entre el mundo del refranero y el de la lírica musical hay como una zona intermedia en que ambos se encuentran y confunden, de tal modo que, en cuanto a la primacía en la génesis de unos y otras, "lo más justo será quizá renunciar a establecer prioridades".

La unidad del torrente de materiales del Vocabulario y el sentido de su mezcla vienen dados por la naturaleza compartida de refranes y géneros breves de la lírica

\footnotetext{
${ }_{9}^{9} \mathrm{Y}$, en efecto, los editores del Vocabulario han localizado los versos correspondientes en el Corpus de la antigua lírica popular hispánica (siglos XV a XVII), Madrid, Castalia, p. 1100; así como en E.M. Torner, Lírica hispánica. Relaciones entre lo popular y lo culto, Madrid, Castalia, $\mathrm{n}^{\circ} 115$. Hay, naturalmente, identificación de correspondencias en otros muchos ejemplos, citados aquí o no.

${ }^{10}$ Como indican R. Jammes y M. Mïr (ibidem, en nota), los versos "Pésame de vos, el conde / porque así os quieren matar", pertenecen al romance del Conde Claros, impreso ya en el Cancionero general de 1511: "En este mismo romance se hallan también otros dos versos célebres ("Que los yerros por amores / dignos son de perdonar"), que Correas apuntó entre los refranes: Los yerros por amores....".

${ }^{11}$ Estas palabras proceden de la otra gran obra de Correas: el Arte de la lengua española castellana (ed. de E. Alarcos García, Madrid, 1954, pp. 398-9, apud Combet, 1971: 29).
} 
popular. Todos ellos son manifestaciones folklóricas del discurso repetido ${ }^{12}$, mensajes destinados a ser reproducidos en sus propios términos, e incorporados a la competencia de los hablantes que forman una comunidad idiomática ${ }^{13}$.

Que un verso, una frase de un cuento o del relato de un hecho célebre se incorpore al habla, significa que se ha producido una lexicalización de la tradición literaria. Pero para que un enunciado literario pase a formar parte del acervo lingüístico de la comunidad hablante, es necesario que se produzca un proceso de fraseologización: es decir, dicho fragmento debe perder su ligazón a un contexto único y adquirir un sentido autónomo ${ }^{14}$. Como unidades fraseológicas ${ }^{15}$, los refranes forman parte del caudal de frases y combinaciones léxicas ya hechas que el hablante emplea en su discurso, y que repite tal cual, transmitiendo ideas estereotipadas en términos fijos (Schapira, 1999: 47 y ss). Un contemporáneo de Correas, el médico cordobés Francisco del Rosal, autor también de un repertorio de refranes, bajo el nombre de fórmulas describe estas unidades como "las maneras de hablar, cuyo orden y modo no se puede alterar si no queremos Barbarizar y destruir el Lenguaje, como hacen oy los Latinos modernos"16. Y, en efecto, la fijación, una de las características que identifican y definen la fraseología, produce una suspensión de las operaciones propias de la sintaxis libre que se manifiesta en el hecho de que las paremias admiten variantes, pero no la modificación de cualquiera de sus componentes. La fijación puede considerarse como un medio básico de creación léxica (Schapira 1999: 12): produce secuencias consolidadas que forman parte del vocabulario al mismo nivel que las unidades simples, en la medida que son listemas, es decir, signos memorizados por el hablante en cuanto a su forma y significado, y que son las unidades a las que se aplican las reglas de la gramática ${ }^{17}$.

\footnotetext{
${ }^{12}$ Noción que fue acuñada por E. Coseriu en 1964, fecha de la primera aparición de su "Introducción al estudio estructural del léxico"; vid. Coseriu (1981: 113-118).

${ }^{13}$ Define así los refranes Lázaro Carreter (1980a: 208-209), quien afirma preferir la expresión “lenguaje literal", pues la literatura sería "repetible", antes que "repetida". R. Almela y J. Sevilla (2000: 11-12) subrayan asimismo que "la paremia, en cuanto texto, forma parte del texto literal".

${ }^{14}$ Vid. Corpas Pastor (1996: 146) donde explica cómo se produce la fraseologización de las citas (enunciados de origen reconocido, a diferencia del refrán, que es anónimo). Remitimos asimismo a la obra de Ch. Schapira (1999), especialmente el apartado consagrado a la "proverbialisation" (1999: 126-131), que define como "processus linguistique qui implique le figement et crée une nouvelle unité lexicale phrastique".

${ }^{15}$ Es decir, combinaciones estables de unidades léxicas formadas por dos o más de dos palabras gráficas, cuyo límite superior se sitúa en el nivel de la oración compuesta; definición con la que excluiríamos, entre otros, los dialogismos: así, Corpas Pastor, de quien tomamos la definición, al tratar de los enunciados fraseológicos (1996: 139) excluye explícitamente de tal ámbito las formas dialogadas. También Schapira (1999: 16) indica expresamente que no tendrá en cuenta los textos que sobrepasen el nivel de la frase. En este trabajo, sin embargo, y, a pesar de la definición, no nos limitamos a los refranes sino que aceptamos el amplio criterio del propio Correas que no excluye de su refranero otros géneros afines.

16 "Y así informar es instruir en la forma, ò poner en forma. Como si a un Paje le mandamos un recado, y le damos palabras prescriptas y ordenadas, y le mandamos que no altere una palabra; y esto es propriamente informar; Aunque oy ya se ha ensanchado este vocablo algo más. [...]" (F. del Rosal [1601] 1976: 392, s.v. informar).

${ }^{17}$ Sobre algunos aspectos de la lexicalización de la literatura, vid. Echevarría y Arbulu (2009).
} 
La fraseología comprende todo tipo de expresiones fijas, desde los enunciados fraseológicos en los queenglobamos los refranes, a las locuciones ${ }^{18}$. Los distintos subtipos de paremia no resultan fáciles de delimitar, pero suele considerarse al refrán como la paremia por excelencia, por ser la unidad que reúne las características de lexicalización, autonomía sintáctica y textual, valor de verdad general y carácter anónimo que suelen caracterizar conjuntamente los ejemplares típicos de esta categoría ${ }^{19}$. El refrán es el núcleo de la obra de la que nos servimos, la unidad que predomina y da título a la obra de Correas y a este artículo. No obstante, nos beneficiaremos de la riqueza heterogénea de nuestra fuente para realizar una aproximación amplia a la paremiología desde el género.

\section{PERTINENCIA DE LA PERSPECTIVA DE GÉNERO}

\subsection{La expresión figurada del género}

La misoginia del refranero es sin duda uno de sus rasgos temáticos sobresalientes, porque son muchos los refranes cuya única razón de ser es el odio por las mujeres. Este carácter resulta tan marcado que el propio Correas se ve obligado a atemperar algunas de sus sentencias; así, tal vez para salvaguardar el crédito del conjunto, a propósito de "La mujer y la candela, tuércela el cuello si la quieres buena" observa lo siguiente: "Tema es de refranes lastimar a las pobres mujeres, y hase de entender que hablan de las menos buenas" (VR, 435) ${ }^{20}$.

Una de las expresiones más claras de la misoginia es la animalización, bien con la identificación plena que se condensa en "Una buena cabra, y una buena mula, y una

\footnotetext{
${ }^{18}$ Véase la tipología expuesta en la obra de Corpas (1996), que adoptamos junto con la terminología escogida por esta autora, entre las múltiples denominaciones concurrentes. También hay locuciones en el Vocabulario -se encuentran en la parte dedicada a las frases proverbiales-, por ejemplo, las siguientes: Venir a cuento (VR, 904), Poner haldas en cinta ("Disponerse a hacer algo", VR, 1045), Fray Jarro ("apodo hecho del vulgo a niños frailillos", VR, 945), Fiesta de tres capas ("muy solene", VR, 954), De poco más a menos ("Decimos hombre, o mujer, o cosa "de poco más a menos", para apocarlos y deshacerlos", VR, 904), De sotaque ("Lo que se da o lleva de más como soborno", VR, 905), A trochimochi ("mal y sin atención", VR, 843), etcétera.

${ }^{19}$ Utilizamos el término paremia, que disfruta de amplio uso como sinónimo de refrán y para abarcar la suma de sentidos de otras denominaciones concurrentes como refrán, proverbio, dicho, máxima, adagio, sentencia, aforismo y apotegma; vid. Corpas (1996: 135 y ss.). Además, el prototipo de refrán presenta otras características adicionales, como son significado metafórico, particularidades fónicas, anomalías sintácticas o estructuras sintácticas particulares en las que sus miembros mantienen relaciones precisas, carácter tradicional y propósito didáctico o dogmático (Arnaud, 1991 y Corpas, 1996). A tal enunciado prototípico corresponde la caracterización de Combet (1971: 58): «une phrase indépendante anonyme et notoire qui, sous une forme elliptique, directe ou de préference figurée, exprime poétiquement un enseignement ou un avis d'ordre moral ou pratique». Vid. en Schapira (1999: 88) una definición de proverbe en forma de listado de rasgos típicos, más numerosos pero no obligatorios.

${ }^{20}$ También diríamos que "tema es" de trabajos sobre el refranero el tratamiento que de la mujer se hace en él, pues son muy numerosas las publicaciones que pintan la imagen que proyectan los refranes de las relaciones entre los géneros, y su papel en la construcción de estos, no solo en la paremiología castellana sino en las otras vecinas y más o menos próximas a nuestra cultura, desde los griegos. Vid., por ejemplo, Calero Fernández (1991), Venier (1985), Reyes de la Rosa (1993) o Tarnovska (2000).
} 
buena mujer, son muy malas bestias todas tres" (VR, 799); o bien mediante asociaciones como las siguientes:

A la galga y la mujer, no la des la carne a ver (VR, 17)

A la mujer y a la gallina, tuércela el cuello y darte ha la vida (VR, 19)

A la mujer y a la picaza, lo que dirías en la plaza; o lo que vieres en la plaza $(\mathrm{VR}, 19)$

La gallina que canta al maitín, y la mujer que parla latín, nunca hicieron buen fin (VR, 419)

Mula que hace "hin" y mujer que parla latín, nunca hicieron buen fin (VR, 540)

No solo la mujer, también la pareja humana es representada por una pareja animal, por ejemplo, el piojo y la pioja, el perro y la gata, el gallo y la gallina, la mula y el caballo, el vulpo y la vulpeja, el sapo y la sapa:

Dice el piojo a la pioja: "¿Adónde vas, compañera? -A tierra de Hombrera. -Es sabrosa, mas es peligrosa". (VR, 225)

El perro en el güeso, y la gata en el mueso. "Mueso" por: la pulpa. (VR, 288)

A la mula con halago, y al caballo con el palo. $\mathrm{O}$ al revés. $(\mathrm{VR}, 19)$

Canta el gallo, responde el capón: ";Guay de la casa do no hay varón!" (VR, 153).

Canta el gallo, responde la gallina: " iAmarga la casa do no hay harina!" (VR, 153)

El vulpo y la vulpeja, todos son en la conseja (VR, 305)

No falta un sapo para una sapa; o Nunca falta un sapo para una sapa $(\mathrm{VR}, 568)$

El toro y la vaca, los animales más importantes en la economía tradicional, se prestan a interesantes reflexiones sobre género y poder. Para En la tierra del rey, la vaca corre al buey (VR, 321), la glosa de Correas dice así: "Porque igualmente se hace justicia al flaco y poderoso, y no hay violencia como suele haber en tierras de señorío", lo cual da buena fe de la confianza popular en la justicia real (Combet 1971:185-186); a la par que nos introduce en la expresión de las relaciones de dominio y obediencia entre los sexos. Idéntica asociación entre género y jerarquía, flacos y poderosos, transmiten otros refranes que utilizan como vehículo las imágenes con toros y vacas:

$\mathrm{Ni}$ temas toro, ni acoses vaca. En la alegoría tiene entera verdad este refrán: que no temas al valiente, ni en derecho te rindas al poderoso, ni acoses mujer ni persona flaca. (VR, 556)

Tira el buey, tira la vaca, más puede el buey que la vaca. Buen refrán, y aviso para avenirse la mujer con su marido, y el flaco con el poderoso, antes de llegar a bregas. (VR, 775)

Tampoco falta la constatación del poder de las mujeres, como cuando "Más manda la mala con su rabo que el rey con su reinado" (VR, 496). Y el repudio de toda subversión, ya sin animales interpuestos: Tiraos, padre; posarse ha mi madre; [o] sentarse ha mi madre, dice Correas que “Es: querer quitar al bueno de la dinidad, para poner al ruin y menos dino" (VR, 775).

Las glosas permiten verificar una elocuente alianza conceptual entre mujeres y sirvientes. Así, Quien muda lado, muda estado, se aplica a "La viuda que mejora 
casamiento; y el que se arrima a mayor señor" (VR, 688) ${ }^{21}$. Y en la explicación que sigue a Bien haya el guijón, que me tornó a mi honor, Correas indica que, además de dar a entender "que sean las mujeres aliñadas y limpias, y bien advertidas con sus maridos"; se toma también "el guijón" por "el castigo y sofrenada con que se corrigen descuidos y se enmiendan las mujeres y los inferiores, y ganan con su enmienda y advertencia la gracia de sus maridos y mayores; y ansí les hace buena obra el castigo, y quien se le da" (VR, 124).

Volviendo a las abundantísimas metáforas, debemos reparar en que la categoría gramatical de género permanece como disponibilidad metafórica ${ }^{22}$, que permite que la pareja humana sea significada por cosas cuyas denominaciones se relacionan a través de la flexión, como la caldera y el caldero, o la acenoria y el acenorio:

Con un caldero viejo comprar otro nuevo, y con una caldera vieja comprar otra nueva. Lo primero dice la moza que se casa con viejo y le espera heredar; lo segundo el mozo que casa con vieja. Es graciosa semejanza del trueco de tales vasijas (VR, 185).

Doña Acenoria viuda, pide la den adyutorio, porque no tiene acenorio (VR, 244).

Finalmente, comprobamos que la oposición de género representada o expresada también por el género gramatical de zoónimos y otros nombres comunes, está cargada de valores semánticos simbólicos y esenciales. Según Correas, preguntar ¿Qué tenemos, hijo o hija?, "Es como decir sí o no, bien o mal" (VR, 673). En otras palabras, en un plano abstracto, las relaciones de género sirven para manifestar las nociones lógicas de antonimia y contradicción, personificadas por hombres y mujeres, a causa de los conflictos que mantienen.

\subsection{Género y especie. Oportunidad de la perspectiva de género}

La oposición gramatical de género se considera una oposición binaria privativa, cuyo término marcado expresa positivamente una propiedad, mientras que el no marcado posee una doble función: es el valor neutro o no marcado, indiferente a la noción distinguida; pero además, en cuanto término opuesto al marcado o caracterizado, supone la ausencia o la negación del término marcado. Así, los empleos del término marcado con su valor neutro son casos de neutralización ${ }^{23}$. Ahora bien, muy a menudo las estructuras de la lengua son perturbadas e incluso corregidas por la fuerza de los usos sociales, que pueden acabar imponiéndose a la razón gramatical. Es

\footnotetext{
${ }^{21}$ La interpretación de Correas proporciona otras muestras: Hacer bailar el agua adelante significa "mucho cuidado en servir y dar gusto a quien se sirve, señor o marido" (VR, 962); Hallar en pesos falsos. Hallar en mal latin, es decir, hallar haciendo trampas "A mujer, o mozo" (VR, 971-2).

${ }^{22}$ Tomamos este análisis de P. Violi (1991: 54), quien se expresa como sigue: “Con otras palabras, puede afirmarse que el profundo carácter semántico que ha originado la categoría gramatical permanece como disponibilidad metafórica siempre presente en el idioma, como una posibilidad abierta para producir efectos sensoriales incluso allí donde el simbolismo primario no se percibe". Véase, además, el excelente artículo de F. Bravo (1992) sobre el muy interesante asunto de la creación de antónimos por el procedimiento de la antonimia fónica o antifonía.
}

${ }^{23}$ Vid. a este respecto Pena (1999: 4.344) y Ambadiang (1999, § 2.2.6.). 
lo que apreciamos en Como hombre es mujer y vieja, hacen burla de hombre. Como hombre está preñada, no se puede abajar: "Dicho de mujeres aldeanas, y tiene gracia en llamarse 'hombre' “ (VR, 174) ${ }^{24}$. El ejemplo constata el uso popular (tal vez dialectal) de hombre en la acepción 'ser humano', empleado también para mujeres solas, y que es heredero del latín homo, y puede además ser interpretado como una neutralización de la oposición mujer / hombre. Pero el comentario de Correas prueba asimismo que el sentido 'varón' parece usurpar el terreno de 'ser humano', al menos en usos de más prestigio que el propio de las aldeanas de Sayago. Y así lo advierte un siglo después el Diccionario de Autoridades:

Viene del Latino Homo, que significa esto mismo: y aunque el verdadero significado desta voz comprehende hombre y muger, en Castellano se toma regularmente por el varón. En lo antiguo se decía Home" (Autoridades, IV: 168).

El Refranero discurre acerca del género humano, de todos cuantos son personas, pero también les particulariza como mujeres y hombres. En el comportamiento del pronombre quien advertimos que puede referirse al ser humano en general: $A$ quien no tiene nada, nada le espanta $(\mathrm{VR}, 34)^{25}$. Pero sin duda hay también un quien inequívocamente masculino:

Quien más no puede, cabe su mujer se acuesta y duerme $(\mathrm{VR}, 685)$

Quien quisiere tener placer, déla de palos a su mujer (VR, 694)

Santo Tomé, quien no tuviere puerco mate la mujer $(\mathrm{VR}, 725)$

$\mathrm{Y}$ un quien femenino:

Quien mal marida, siempre ha qué diga (VR, 684)

Quien mal marido tiene, nunca se le muere (VR, 684)

Quien quiere que su marido viva poco, déle a comer sardina en agosto (VR, 692)

Quien mucho mira, poco hila (VR, 687)

Quien por la Madalena vela, echa buena tela (VR, 690)

Quien por San Bartolomé no vela, nunca hace buena tela (VR, 690)

Este quien femenino corrobora la idea de que entre las voces que es posible escuchar en el Refranero las hay de distinto género, y que los refranes tienen destinatarios específicos, como prueban los quien masculinos y femeninos que señalamos, en enunciados que se dirigen distintamente a hombres y mujeres, porque procuran la educación particular propia de hombres y diferente de la de las mujeres. Está claro que, de los siguientes, los primeros hablan a los hombres y los últimos a las mujeres:

Guarte de puta, que deja la bolsa enjuta $(\mathrm{VR}, 368)$

A fraile no hagas cama, de tu muger no hagas ama (VR, 13)

\footnotetext{
${ }^{24}$ Correas explica el dicho en otro lugar, a propósito de la expresión Es un sayagués: "Para notar a uno de grosero, porque los de Sayago son toscos en traje y en habla, no por falta de entendimiento, que le tienen bueno debajo de la corteza rústica. [...] En Salamanca llevaron una sayaguesa ante el corregidor, y al salir preguntóla otra: “CCómo os ha ido?"; ella dijo: "Como hombre era mujer y vieja, no hacen caso de hombre"; con que significó el mal despacho" (VR, 342).

${ }^{25}$ Otros ejemplos análogos: Quien consigo se aconseja, consigo se lleva la pena (VR, 680); Quien cuando puede no quiere, cuando quiere no puede (VR, 680); A quien no habla no le oye Dios; o A quien no llama no le oye Dios (VR, 34), etcétera.
} 
Aunque con tu mujer tengas barajas, no metas en tu casa pajas (VR, 109)

A la pared mea quien te amansará (VR, 29)

A las diez, deja la calle para quien es. Que se recojan las mujeres que se sientan a sus puertas a las noches del verano, porque ya la calle es para rondadores $(\mathrm{VR}, 22)$

Come, y duerme, y engorda; si te llamaren hazte sorda $(\mathrm{VR}, 169)$

Guarte del sol de marzo, y estarás hermosa todo el año (VR, 368), etcétera,

Así pues, a menudo hemos de especificar un género en la interpretación de términos neutros; sin embargo, no es menos significativo notar que, inversamente, se perfila una larga serie de paremias y expresiones fijas que utilizan motivos femeninos que se emplean con sentido genérico o humano. Véase, por ejemplo, A la miel, golosas; y al aceite, hermosas: "A la miel, golosas" se dice cuando acuden muchos a cosa que les lleva el deseo a participar della", dice Correas (VR, 18; cursiva nuestra). Puesto que esta función es la del masculino (género no marcado o inclusivo), consideraremos que las mujeres encarnan una metáfora del ser humano, análogamente a lo que se ha dicho de parejas de animales y cosas respecto a la pareja humana:

Con lo que Sancha sana, Marta cae mala (VR, 183)

Díselo tú, Marigüela, que yo no lo entiendo (VR, 235)

Hable mi vecina, y tenga mi costal harina (VR, 374)

No halla Menga cosa que la venga. Mal contentadizos (VR, 569)

Espantóse la muerta de la degollada, como la vio tan desgreñada; o tan mal tocada $(\mathrm{VR}, 519)$

Lo que a la tuerta el ojo; [o] Como a la tuerta el ojo (VR, 462)

Quitáronlo a la tuerta, y diéronlo a la ciega (VR, 703)

En cuanto fui nuera, nunca tuve buena suegra; y en cuanto fui suegra, nunca tuve buena nuera (VR, 311)

Ruéganla que se pea, y cágase. Mofa de los demasiados, que no paran la tarabilla de hablar hasta que muelen y cansan; como la otra, dura y porfiada en comenzar a bailar, y mucho más en no dejarlo. (VR, 714)

Perdió la vieja los dientes, mas no las mientes (VR, 633)

Meneaos, Lucía, que estáis dormida (VR, 516)

Cualquiera de los anteriores enunciados requiere una interpretación no apegada al género femenino de las figuras a las que se refieren. La mayoría de los refranes se aplican al discurso de forma metafórica. Por ejemplo, Si la fregona no fregase el mortero, ¿en qué comería el majadero?, según Correas, "Responde y muerde la moza al que la llama "fregona", y da a entender que no se ha de denostar a ninguno por el oficio y estado en que se sustenta honestamente (VR, 736). Literalmente tenemos una fregona que, figuradamente, habla de cualquiera que sirve y trabaja honradamente; análogamente, las incontables putas, viejas, comadres y vecinas que pueblan el Refranero representan personajes convencionales, en escenarios fácilmente identificables por la comunidad, que sirven para transmitir significados genéricamente humanos. 


\section{VOCES DE MUJERES}

\subsection{Las personas del refrán}

Las figuras femeninas aparecen a menudo representadas por su propia voz, lo que nos deja observar cómo hablan las mujeres en los refranes. El repertorio de Correas permite comparar variantes de refranes que difieren en cuanto a la persona gramatical del sujeto de la enunciación. Por ejemplo, en este: Si con el rey se echó, puta se halló; que, según Correas, "Varíase": Si con el rey te echaste, puta te quedaste; Si con el rey me eché, puta me quedé (VR, 731). En las diferencias se recogen todas las posibilidades gramaticales de la voz del refrán.

Las personas del diálogo, yo y tú, que se utilizan para describir una situación de la que al mismo tiempo se participa, actúan asimismo como vehículo retórico pues sirven para precisar al máximo, proporcionando una ilustración viva y dramatizada del mensaje que se transmite, frente a los términos indistintos de un discurso genérico. Es posible concebir una escala de abstracción, uno de cuyos extremos corresponde a los enunciados impersonales, estando el concreto ocupado por aquellos que contienen marcas de oralidad y fundamentalmente de diálogo ${ }^{26}$ : Dice la madre: “¿Qué quieres, hija? -Que me llamen regaladica". Dice la hija a la madre: "Que me deis con quien me regale". (VR, 225)

El diálogo es el molde lingüístico que permite explicar otras paremias, también habladas, pero como soliloquio que no obtiene respuesta. Un sinfín de estos enunciados se distinguen porque una voz femenina refiere en primera persona sus experiencias, reflexiones y sentimientos:

Mal me quieren mis comadres, porque las digo las verdades; bien me quieren mis vecinas porque las digo las mentiras (VR, 484)

Más gorda está la gallina de mi vecina que la mía (VR, 495)

Más quiero el niño mamoso que hermoso (VR, 498)

Mi marido es cucharatero, Dios me le dio y ansí me le quiero (VR, 521)

La subjetividad que caracteriza estas formas habladas proporciona un modo más concreto, expresivo e intenso de afirmar lo mismo; y añade un importante valor a lo comunicado, cual es el que aporta la experiencia como fuente de legitimidad del conocimiento. Por ejemplo, Quien tuviere hija fea, compre un majuelo; que ansí hizo mi padre, y casóme luego (VR, 701), en que, aunque sea con ironía, el añadido personal serviría para demostrar la eficacia del consejo.

\footnotetext{
${ }^{26}$ Aunque excede el propósito de este trabajo, remitimos al estudio de Abascal (2004), como compendio de perspectivas sobre la oralidad, uno de cuyos géneros es el refrán. Además, en el caso que nos ocupa, la oralidad fingida es un recurso expresivo.
} 


\subsection{Voz de mujer denotada}

En este apartado veremos algunas muestras inequívocas de voces de mujeres, y, en primer lugar, las de los personajes femeninos que hablan en los refranes dialogados o combinaciones de al menos dos enunciados que corresponden a distintas voces, cuyos géneros están expresamente marcados.

Dialogan hombre y mujer, por este orden de intervención:

Bésame, moza, darte he una pera. -Quitate allá, que tienes bohera. (VR, 122)

En nombre de Dios te estreno, hija de mi suegro. -Majadero, no sois vos el primero. (VR, 325)

Mariquita, ¿y en sábado ciernes? -Ay, señor, pensé que era viernes. (VR, 492)

Mi reina, ¿qué tanto ha que no se peina? -Mi galán, desde San Juan (VR, 522)

Juana, ¿en lo tuyo tienes lana? -Lana y vellocino, mas no por vos, $h 4 d 3 d 4 ;$ [o] mezquino. (VR, 405) ${ }^{27}$

Juana, de vos hagan una gaita. $-Y$ de vos, mezquino ([o] h4d2d4) hagan un tamborino; y luego, majadero, hagan un pandero. (VR, 405)

¿Vos, cómo os llamáis? -Yo, Elvira. -¿Y vos? -Yo, Elvirote, por mordella. (VR, 819)

Dialogan mujer y hombre, en este orden:

Acúsome, Padre, que soy puerca. - No lo digáis, hija, que bien se os parece (VR, 44)

Entra en casa, Juan García. -Deja el palo, mujer mía (VR, 332)

Cornudo sois, marido. -Mujer, ¿y quién te lo dijo? (VR, 188)

Marido, cornudo sodes. -Mejor es que hinchar odres (VR, 491)

San Vicente, yo juro y tú tente; que la que a su marido encornuda, a la horca le suba, y si vos lo cr[e]éis, en la horca perneéis, y si yo lo hago, que muráis ahorcado, y si os falta soga, yo os dé otra; [o que si os falta soga, yo os daré otra.] -No juréis, mujer querida, que ya sois creída (VR, 724)

Diálogos entre mujeres (madre e hija, vecinas y comadres...):

Madre, ¿qué cosa es casar? -Hija, hilar, parir y llorar (VR, 481)

Comadre andariega, no vó a parte que no vos vea. -Si vos, comadre, estuviésedes en vuestra casa con la pierna quebrada, no me veríades en cada casa (VR, 168)

¿Tenéis lumbre, Doña Lucía? -La de Dios, Doña Mencía (VR, 769)

\section{U otras cualesquiera, incluso brujas:}

Brujas, estrigas de chipitín boca, desta casa no llevaréis sangre ni gota. -Ni désta ni de otra... ni de siete casas a la redonda... ni de siete calles ni villas a la redonda. - No señora, que nos echaréis a perder a todas.

Es el cuento: que una señora honrada ganó la voluntad a una bruja, para que la dijese cómo se defenderían de las brujas; ella dijo lo primero deste diálogo; la señora añidió: "Ni désta ni de otra", y concedió la bruja; y segunda vez añidió: "siete casas"; y tercera: "siete casas y siete vilals"; a esto volvió la bruja: "No, señora, que nos echaréis a perder a todas". Y esto último puede ser refrán. "chipitín boca" alude a tres etimologías: de "chapa", de "chape", de "chupar" (VR, 131)

\section{Y una mujer responde a un interlocutor neutro en cuanto al género:}

Casadica, de vos dicen mal. -Digan, digan, que ellos cansarán (VR, 158).

Colorada estáis, nuestra ama. -Vengo del horno y diome la llama (VR, 167).

Dama, ¿quién os hizo tan aguda? - Agua caliente y levadura (VR, 216).

\footnotetext{
${ }^{27}$ Son refranes escritos en clave para eludir las palabras malsonantes. Las equivalencias vocálicas usadas Correas son las siguientes: $\mathrm{a}=, \mathrm{e}=2, \mathrm{i}=3, \mathrm{o}=4$ (vid. Combet, 2000: $\mathrm{XXX)}$.
} 
¿Qué hacéis, Madalena Gil? -Mato las pulgas al candil (VR, 669).

Si te casas con Juan Pérez, ¿qué más quieres? -Que repique los cascabeles (VR, 746).

Asimismo, son hablantes visiblemente femeninas aquellas que bien por razones de implicación léxica, bien por la evidencia de la flexión gramatical se declaran como tales. La concordancia de género y los pronombres delatan una voz de mujer en

Agora, agora, agora que estoy sola (VR, 46)

Aunque me veis que descalza vengo, tres pares de zapatos tengo: unos tengo en el corral, otros en el muladar, y otros en cas del zapatero; tres pares de zapatos tengo $(\mathrm{VR}, 110)$

Aunque soy manca de la mano, no de la calderita del rabo (VR, 111)

Aunque soy tosca, bien veo la mosca (VR, 111)

Cuitada de mí, que aquí lo puse y no lo hallo aquí ni allí $(\mathrm{VR}, 212)$

Díceme mi madre que soy bonitilla; sábelo Dios y la salserilla $(\mathrm{VR}, 226)$

Duelos me hicieron negra, que yo blanca me era (VR, 245)

Híceme enferma por ser visitada, que si me muriera quedárame burlada $(\mathrm{VR}, 388)$

$N i$ soy buena, ni soy mala, ni se me tienen los pies en casa (VR, 555)

No me toquéis al aldaba, que no soy enamorada (VR, 582)

Por eso soy yo muy mala, porque digo las verdades y riño lo malo a la clara (VR, 647)

Que no quiero ser casada, sino libre y enamorada (VR, 671)

Si yo dijera "No quiero, no quiero", no fuera yo amiga del crego (VR, 748)

Yo rascada, y vos querellada (VR, 828)

En cuanto a los indicios léxicos, es muy repetida la expresión mi marido:

Castigóme mi marido con ramo de hinojo, siete meses estuve de mal de coscojo (VR, 161)

Cuándo del pie, cuándo de la oreja, a mi marido nunca le falta queja (VR, 195)

Díceme mi marido que no hile, sino que me ponga a la puerta y mire (VR, 226)

Esperando marido caballero, lléganme las tetas al braguero; o danme las tetas por bajo del pecho (VR, 349)

Las malas tijeras hicieron a mi marido tuerto (VR, 454)

Mi marido es viejo, hermana, no puede subir a la cama $(\mathrm{VR}, 521)$

Mi marido no juega a los dados, mas hace otros malos recaudos (VR, 522)

Mi marido va a la mar, chirlosmirlos va a buscar (VR, 522)

"Lo bien hecho, bien parece". Y estaban ahorcando a su marido en la plaza (VR, 460)

"Arremete, toro, que yo sé que eres bravo." Y miraba a su marido (VR, 104)

Otros refranes evocan más claramente un contexto de diálogo al contener una referencia a un interlocutor en segunda persona o una interpelación, resumiendo en un enunciado diálogos semejantes a los vistos:

Ayúdame a zamarrear a mi mariduelo, que le tengo en el suelo (VR, 115)

¡Aceite de cepas, marido, que me fino! (VR, 43)

Caldo de uvas, marido, que me fino (VR, 149)

Cansado venís, marido de arar; ¿qué me hiciera, si hilárades? (VR, 153)

Cual vos sois marido, tal carne traéis: de la punta del cuerno os la dan cada vez $(\mathrm{VR}, 193)$

Amárgame el agua, marido; amárgame, y sábeme el vino (VR, 78) 
Marido, buscá otra renta, que cuesta muy cara la cornamenta (VR, 490)

Veis aquí, marido, cómo nos perdemos: vos para poco, y yo para menos (VR, 808)

No creáis, marido, lo que vos viéredes, sino lo que yo os dijere (VR, 561)

No es nada, sino que matan a mi marido; [o a mi marido] matan (VR, 566)

Igualmente explícitos son los que exhiben un nombre propio ( Aldonza soy sin vergüenza, VR, 71), o la autocalificación de la hablante mediante nombres como vieja, moza, puta, suegra, nuera, etc.:

Ande la loza, que de vieja me tornaré moza (VR, 87)

Ahora que soy moza, quiérome holgar; que cuando sea vieja, todo es tosejar (VR, 51)

Cuando yo era moza, meaba por un punto; ahora que soy vieja, méolo todo junto (VR, 208)

Cuando yo era moza, queríanme los mozos; ahora que soy vieja, burlan de mí todos (VR, 208)

Esta burra me ha de hacer puta, que me lleva a los pastores (VR, 349)

Mentís, doña vieja: que yo fui puta, mas no pelleja (VR, 516)

Mirad quién me llamó puta, sino la Méndez (VR, 526)

Miren quién me llamó puta, sino otra más disoluta (VR, 526)

Yo dueña y vos doncella, ¿quién barrerá la casapuerta? (VR, 826)

\subsection{Voz de mujer connotada o inferida}

En las muestras vistas hay evidencias lingüísticas inequívocas de una voz femenina. En cuanto a los indicios léxicos, es indudable que marido contiene un rasgo semántico relacional ' (consorte) de mujer' y que la expresión mi marido implica ${ }^{28}$ por ello un hablante femenino; pero la necesidad de los rasgos semánticos en los significados parece una cuestión de grado, que va de lo imposible a lo obligatorio, pasando por lo esperable $^{29}$. Si en vez de mi marido tomamos mi rueca, lo más probable y esperable es también que lo diga una mujer, y consideramos voces de mujer todas las que siguen porque, por razones de probabilidad contextual, interpretamos que es mujer quien habla. Será mujer quien se refiera en primera persona a objetos y actividades "propios de mujeres", y que así son percibidos:

Mi aguja y mi dedal, cien doblas val (VR, 519)

A buscarla ando, la mala de la rueca, y no la hallo (VR, 6)

\footnotetext{
${ }^{28}$ Utilizamos implicar en su uso corriente, sin que implicación se entienda aquí por implicación lógica. En ese caso tendríamos que utilizar otra denominación, como hace, por ejemplo, García Murga (2002: 12-20), quien distingue entre entrañamiento e implicación lógica; esta es independiente del contenido y dependiente de la forma lógica, pues establece relaciones entre formas, sin atender al significado de los términos que aparecen en las formas. De modo que el término apropiado sería entonces entrañamiento (que traduce el término inglés entailment).

${ }^{29}$ Entre las dimensiones del significado descriptivo, Cruse (2000: 54-58) distingue las que llama "dimensiones relativas", concernientes a rasgos semánticos más que a significados léxicos completos. Diferencia relaciones lógicas necesarias y contingentes, pero observa que lo verdaderamente útil sería reconocer una escala de necesidad. Lyons (1981) había diferenciado necesidad natural, para las expectativas basadas en las leyes de la naturaleza, y necesidad social, para las basadas en las leyes y convenciones sociales. Cruse propone también necesidad canónica para casos como el de cuadrúpedo del que esperamos que, en su "forma canónica", tenga 'cuatro patas'.
} 
A mí no puedo, y a mis comadres hilo (VR, 24)

Daime la bota, y quítame la toca; una me cansa, y otra me conforta (VR, 216)

El chichón de la mi barriga, mucho me crece, no sé qué os diga (VR, 264)

El día que no escobeé, entró quien no pensé (VR, 266)

El lunes mojo, el martes lavo, el miércoles cuelo, el jueves saco, el viernes cierno, el sábado amaso, el domingo que yo hilaría, todos me dicen que no es día (VR, 277)

La servilla al pie, en mal punto me la calcé (VR, 444)

La jervilla al pie, en mala ora [sic] me la calcé. Que suceden cada rato cosas no pensadas. "Jervilla" es zapato de mujer, abierto por el atar; algunos dicen "servilla", como "sastre" y "jastre". (VR, 423)

Alfaya, por alfaya, más quiero pandero que no saya $(\mathrm{VR}, 71)$

Con deseo de zuecos, calcéme estos pucheros (VR, 180)

Por deseo de chapín, metí mi pie en este celemín (VR, 645)

Quítese allá, señor Don Miguel; apártese allá, que le enharinaré (VR, 704)

Regañar, regañar, que no se le tengo de remendar $(\mathrm{VR}, 707)^{30}$

Los refranes que evocan situaciones de diálogo también nos permiten aplicar un criterio de expectativas en cuanto al género de los interlocutores, a base de lo que es esperable. Los intercambios comunicativos que escenifican los productos folklóricos no son infinitamente variados, sino que reflejan contextos y relaciones sociales típicas. Las mujeres se relacionan habitualmente con otras mujeres, y a no ser que se indique, es natural esperar que en los refranes quien llame a la madre sea la hija y no el hijo, y que se representen diálogos entre dos vecinas o comadres, entre suegra y nuera. Por ello, consideraríamos que las siguientes serán voces de hija y no de hijos:

A coger amapolas, madre, me perdí; caras amapolas fueron para mí (VR, 8)

Madre, casadme cedo, que se me arrufa el pelo (VR, 480).

Madre, casar, casar, que Zarapico me quiere llevar (VR, 480)

Castígame mi madre, y yo trómposelas; [o] Ríneme mi madre... (VR, 160)

Y de madre (y no padre):

Adelántate, hijuela, y llámale cornudo (VR, 45)

Mi hija que hipa, de hambre está ahíta; mi nuera que boceza, de harta está tesa (VR, 521)

Vaya con Dios mi hija con su marido; si la matare, si no, vuélvase a casa $(\mathrm{VR}, 806)$

La observación de Correas coincide en esta tesis de la tipicidad de los diálogos cuando asegura que Más quiero amiga llana que parienta falsa "Dícenlo mujeres" (VR, 498). Por eso inferimos que es mujer (suegra, comadre o vecina) el sujeto enunciador de los siguientes:

A mi nuera, echando agua y harina, la crece la masa entre las manos (VR, 22)

¿Vistes allá a mi nuera, la de los pabilones en la rueca? (VR, 816)

Comadre andariega, donde vó, allá vos fallo; o adonde voy, allá os hallo $(\mathrm{VR}, 168)$

\footnotetext{
${ }^{30} \mathrm{Y}$ Estos mis cabellitos, madre, dos a dos me los lleva el aire (VR, 354), también podemos reconocer a una mujer, porque esperamos de ella que valore sus cabellos de un modo impensable en un hombre, además de que el uso de diminutivos es más frecuente y propio de mujeres y niños.
} 
Agradecémelo, vecinas, que doy salvado a mis gallinas (VR, 46)

Agradecémelo, vecinas, que quiero bien a mis hijas (VR, 47)

Bien me quieren mis vecinas, porque las digo las mentiras (VR, 125)

Fuime a mis vecinas, y avergoncéme; volvíme a mi casa, y consoléme (VR, 361)

Hable mi vecina, y tenga mi costal harina (VR, 374)

La cabra de mi vecina tiene un pie más que la mía $(\mathrm{VR}, 413)^{31}$

\subsection{Voz femenina atribuida por Correas en la explicación o en la interpretación}

Correas introduce frecuentes historias explicativas en las que aparecen personajes femeninos cuyas palabras son responsables de las paremias. A veces narra una historia, cuento o chiste, aunque sea en breves pinceladas, y otras veces presenta una interpretación. Se patentiza de esta manera el hecho conocido de que muy numerosos relatos folklóricos han llegado a nosotros "bajo formas de puros esquemas, y en ocasiones en la forma residual de unas frases alusivas cuyo sentido hemos de descifrar", en palabras de M. Chevalier (1978: 29-30), quien aprecia que "sobre todo es manifiesto el fenómeno en el refranero, si aceptamos la idea de leerlo como colección de cuentos tradicionales y no únicamente como repertorio de proverbios" (ibidem).

El refrán puede preceder a la historia (y en alguna ocasión así se dice), de modo que nos encontramos con ilustraciones literarias del uso de los refranes:

No escupiré, aunque me ahogue. Quería escupir la mujer y dijo al marido que la diese lugar; dijo él: "No escupáis, que me iré de la cama"; ella le detuvo diciendo: "No escupiré, aunque me ahogue". Fíngese el cuento para refrán, y el refrán para el cuento. (VR, 567)

Quien va pidiendo, no viene corriendo. Porque no le despachan como quiere. Iba una moza a buscar sus aventuras para ayudarse a sí y a su ama, y no negociando tan presto, se disculpaba con este refrán de la tardanza. $(\mathrm{VR}, 702)$

Jura mala en piedra caya. Está glosado en estas coplas: Pariendo juró Pelaya / de no volver a parir; / y luego volvió a decir: / “jura mala en piedra caya!" / Como era la vez primera / que en esta trance se vía, / dijo que aquésta sería / la primera y la postrera. / Mas no hubo bien alzado / la saya para parir, / cuando la oyeron decir: / "iJura mala en piedra caya". (VR, 368)

Son, sin embargo, mucho más abundantes las historias etiológicas, los ejemplos decuentos desarrollados como contexto literario explicativo de las fórmulas. Escogemos unos pocos:

Aguates, Padre.

Son frutas de las Indias, provocativas a lujuria, como acá piñones, o caracoles, o cantáridas. Confesándose una mulata, hizo escrúpulo de haber comido aguates para cierta ocasión, y en el discurso de la confesión y al cabo della, el confesor la preguntó veces, para tener memoria qué fruta era aquella que había comido; y ella respondía: "Aguates, Padre", tanto que ella notó malicia de hacer él memoria, si para otro tal fin era. Aplícase a propósitos de tales curiosidades en Indias, por la gana que él mostró de conocer la fruta y su propiedad. (VR, 49)

\footnotetext{
${ }^{31}$ Naturalmente, también hallamos diálogos entre hombres y mujeres, como los amorosos y otros: Parecéis molinero, amor, y sois moledor. Al que es pesado y cansativo. (VR, 624) Vecina, mucho os lo ruego. -Mi fe, compadre, no quiero. (VR, 807); etcétera.
} 
Apartalde del manzano, no sea lo de antaño.

Que se guarden los hombres de no errar dos veces en una cosa. Es el cuento: que un hortelano se fingió muerto para tentar y saber lo que tenía en su mujer; y llevándole a enterrar, descansaron en el camino y pusiéronle junto a un manzano; allí se asió de un ramo y volvió en sí de la muerte fingida. Otra vez, de ahí a un año, murióse de veras, y llevándole a enterrar, avisó la mujer que le apartasen del manzano, no fuese lo de antaño, como si el manzano tuviera virtudes de dar vida. Nótase el desamor de algunas con sus maridos, y de algunos que lo merecen por su dura condición con ellas. (VR, 96).

Brujas, estrigas de chipitín boca, desta casa no llevaréis sangre ni gota. -Ni désta ni de otra... ni de siete casas a la redonda... ni de siete calles ni villas a la redonda. - No señora, que nos echaréis a perder a todas.

Es el cuento: que una señora honrada ganó la voluntad a una bruja, para que la dijese cómo se defenderían de las brujas; ella dijo lo primero deste diálogo; la señora añidió: "Ni désta ni de otra", y concedió la bruja; y segunda vez añidió: "siete casas"; y tercera: "siete casas y siete vilals"; a esto volvió la bruja: "No, señora, que nos echaréis a perder a todas". Y esto último puede ser refrán. $(\mathrm{VR}, 131)$

\section{Caerá la azuela, y matará a Garcigüela.}

Este refrán, y el otro "Los bobos de Sando y Pedernal", nacieron juntos deste cuento fingido: En el tal lugar, dos recién casados, hablando de su gobierno y sucesión o generación, el marido decía uno, la mujer otro, cada uno a su gusto; el marido quería tener un hijo que le ayudase en su oficio de carpintero, la mujer que no, sino una hija, y que le casarían, y della tendrían un nieto, y que le llamarían García; con esto, ya el marido se convencía, y concedióla que fuese ansí norabuena, que al muchacho le enseñaría desde pequeño, y a él le ayudaría; a esto replicó la mujer: "No, no, que caerá la azuela, y matará a Garcigüela". Aplícase a los que con temores impertinentes no se disponen a hacer nada, y se están atados y entumidos, sin aventurarse a hacer lo que les está bien; y a "No asamos y ya empringamos". (VR, 148)

Cruz en lumbre, y cruz en puerta, y cruz en llelda, y no hay sino "entra, entra".

Mandaban a una bruja mozuela otras viejas que entrase delante en una casa para hacer el mal que sueln, y halló cruz en todas las cosas. "Llelda" es: la levadura. Y da aviso que se hagan estas cruces. (VR, 191)

"El bodigo bueno" y "Yo a vos también", no viene bien, mujer. "Mucho [o]s quiero, María. -Yo a vos también", eso viene bien.

En una aldea, llegando a ofrecer una casada, díjola el cura muy bajo: "Mucho os quiero, María"; ella respondió: "Yo a vos también". Estas palabras della, oyólas el marido, y no las del cura, y preguntóla después en casa: “¿Qué os dijo el cura?". Ella trocó la razón: “Que llevaba buen bodigo". Replicó el marido: "El bodigo bueno. -Yo a vos también": no viene bien, mujer". Esaminóla más y confesó la verdad, que había dicho el cura: "Mucho os quiero, María"; ansí concertó el marido las razones: "Mucho os quiero, María. -Yo a vos también": eso viene bien". Acomódase por lo primero a cosas que no conciertan; por lo segundo, a razones y cosas que conciertan. (VR, 257)

\section{Hay argumentos más breves:}

Toda la noche "Mi alma y mi vida", y agora cúpele.

Entró un galán a escuras con una negra por yerro, creyendo era blanca. Decíala: “Mi alma y mi vida", y a la mañana, viendo que era negra, escupió con asco; y siéntese la negra con lo que dice el refrán. Hermano déste es el otro: "Mi alma y mi vida...". (VR, 776)

Regañar, regañar, que no se le tengo de remendar. 
Habíala el marido amenazado y puesto pena que la haría tal cosa, si no le remendaba el jubón. (VR, 707)

Teritar, carnes malditas, que mañana estaréis en tángano.

De una vieja que se había de casar esotro día. “Tángano”, por: tálamo. (VR, 771)

$\mathrm{Y}$ algunas escenas, en las que, más escuetamente aún, unos pocos elementos pintan una situación en la que se propone un hablante en su contexto, que dota de sentido a la frase:

Buen Miguel, si désta te escapas, enmendarás la tu vida. Era travieso, y estando en peligro de muerte se lo decían su madre y sus hermanas. (VR, 132)

Con esto os alumbren a vos, Virgen gloriosa, que no con aceite y malas venturas. Díjolo la vieja por el vino, acabando de empinar un jarro y dalle buen golpe. (VR, 182)

El fraile se muda, el mozo se casa, el casado se cansa y se va a su casa, el clérigo dura; o el abad dura. Consejo de vieja a moza enamorada. (VR, 269)

Estando vos ya güesa, mal haréis aquí presa. La moza llama "güesa" al viejo. (VR, 351)

Éste me salga bueno, que es para el cura. Decía esto una feligresa, limpiando con su delantera un pan que sacaba del horno, aludiendo al otro que estaba debajo del mandil. (VR, 352)

¡Guay de lo que aquí anduvo! Díjolo una vieja dando con el pie a una bragueta que estaba en un muladar. (VR, 369)

Hágale aire, que no está cocido. Esto es: avive la lumbre y aviente, para que cueza el puchero. Quería decir con este símil una dama a su pretendiente que la diese más y más, que aún no la tenía bien sazonada y satisfecha. (VR, 378)

Hasta ver las armas del mal logrado. Dicho por viuda, bebiendo en la taza antigua y grande que en el hondo tenía las armas del marido. (VR, 383)

Ni por vos ni por otro, sino por este zapato que está roto. Respuesta, preguntada la dama por quién suspiraba. $(\mathrm{VR}, 554)$

Finalmente, Correas imagina a las mujeres hablando y el coloquio femenino procura la comprensión de la frase. Nótese que no cuenta aquí historias tradicionales sino que se limita a presentarnos una escena típica de su tiempo, vinculando algunas expresiones a sus usuarios más habituales:

A la mujer casera, el marido se la muera.

Suelen parecer caseras algunas mujeres casadas, y ser alabadas sus caserías y granjeos, lo cual luce, porque gana y lo gobierna el marido, que allega la hacienda y lo cumple todo. Las otras, con envidia o con prudencia, dicen: "Pocas gracias, si el marido se lo lleva a casa; muérase el marido y quede sola, y entonces veremos si es casera; antes, no se alabe, que no la sabemos". Éste es el sentido deste refrán, no el que le dio el Comendador, que es que se sabrá valer por sí; lo cual no es culpa en ella ser casera, para condenarla a que se la muera el marido; que antes con él lo será mejor, y lucirán y criarán bien sus hijos. No le entendió Malara, o Mal Lara" (VR, 19) 
A tu hija muda, véasla viuda.

Este refrán habla como el otro: "A la mujer casera, el marido se la muera". Aquí dicen lo mesmo las viudas, defendiéndose: si tu hija es callada y no se queja como las viudas o malcasadas, múdese el marido en perdido, o enviude, y luego la verás que llora lástimas y tiene querellas (VR, 38).

Antes santa que nacida.

Lo primero es de Nuestra Señora, [...] Lo segundo y ordinario, cuando ven alabar una mujer de virtuosa, o una madre a su hija, las otras, con enfado o envidia, dicen con desdén e ironía: "Sí por cierto, antes santa que nacida", como decir: "No es todo vero lo que dice el pandero" (VR, 93).

\section{FRASEOLOGÍA DE MUJERES}

Hemos examinado un nutrido conjunto de paremias que presentan semblantes femeninos fingidos, voces de mujer representadas para transmitir sentidos figurados que transcienden a menudo su género, porque sirven para hablar de las mujeres, o bien para por medio de mujeres hablar de otras cosas. Pero los últimos ejemplos facilitan el tránsito a una clase diferente de expresiones con o sin personajes femeninos, dialogados o no, pero que pueden considerarse refranes de mujeres, propios de mujeres, usados distintivamente por ellas.

En la fraseología, como en el léxico, se dan interesantes diferencias que atañen a la geografía, a la diacronía y a los registros o niveles de uso. Nos preguntamos si el género es un parámetro de variación en fraseología. Es decir, si hay o ha habido diferencias en el uso de refranes y otras expresiones por parte de hombres y mujeres. La respuesta es afirmativa así que veamos cuál es la naturaleza y el calibre de esas diferencias.

\subsection{Marcados por Correas}

Sabemos con certeza que algunas expresiones fijas, incluidas las paremias, son típicas o propias de mujeres, porque es el propio Correas quien de ello nos informa. Nuestro autor observa algunas peculiaridades del comportamiento comunicativo de las mujeres, sin que quepa ahora mencionar otra cosa que los tópicos sobre su verbosidad como en Dijo de una hasta ciento, "Cuando uno, enojado, dijo mil oprobios; o el que dijo muchas mentiras y vaciedades. Es más propio de mujeres" (VR, 227). O las peleas femeninas en las que Dijéronse los nombres de las Pascuas, "Esto es: los nombres grandes y solenes; llamáronse "bellacas", "putas”, "alcagüetas" (VR, 227), donde el femenino está indicado en el género de los apelativos.

Fijémonos en que una de las expresiones del Vocabulario es, precisamente, una fórmula presentadora de enunciados:

Dicen las mujeres.

Por hablilla; que las preñadas encubren su preñez, y no la dicen hasta que ella se descubre, porque dicen que si lo dicen sale fea la criatura: También que si el niño se mea en la pila, que tendrá más hermanos (VR, 912). 
La expresión es claramente despectiva, a juzgar por los ejemplos y por el significado de hablilla: "Cuento que no tiene fundamento, mentira que semeja a la verdad, historia fabulosa" (Autoridades, IV: 110). Precisamente, el Vocabulario registra una serie de creencias y supersticiones propias de la cultura femenina: Los amores que comienzan en Cuaresma duran más, dicen las dueñas (VR,470); Si no fuese por la ruda, no habría criatura, "Dicen las mujeres" (VR, 739); Si supiese la mujer que cría las virtudes de la ruda, buscarla ía de noche a la luna, "Éste cantan también las brujas" (VR, 745); Con la hierbalán y la ruda, no se muere criatura, "según opinión de mujeres" (VR, 182); El remolino al lado, señal de otro hermano, "es dicho de comadres" (VR, 297); La que besare el pie de San Cristóbal será bien casada, "Dicen esto las mujeres, por burlar de otras que todo lo creen" (VR, 985), etcétera.

Las expresiones lingüísticas atribuidas por Correas al uso femenino corresponden a distintas categorías, pero la más importante consta de refranes y fórmulas:

Hombre besador, poco empreñador. Este refrán inventaron las mujeres. (VR, 394)

Lo que la mujer quiere, Dios lo quiere. Dícenlo ellas, que son amigas de su parecer. (VR, 465)

Más quiero amiga llana que parienta falsa. Dícenlo mujeres. (VR, 510)

Más valen tocas negras que barbas luengas. Escoge la mujer que muera el marido antes, y traer luto por él, que no que él le traiga por ella. $(\mathrm{VR}, 510)$

Más valen tocas que capuz. Escoge que, mal por mal, muera el marido primero. (VR, 510)

Las fórmulas ${ }^{32}$, que componen un grupo verdaderamente nutrido, nos sitúan mejor en la vertiente pragmática de la fraseología, ya que desempeñan papeles específicos en la comunicación: alabar y lisonjear, bendecir y maldecir, amenazar, imprecar, reñir, expresar alegría, enfado, sorpresa y otras funciones discursivas propias de apoyos o bordoncillos que se insertan en la conversación. Uno de estos es Como digo de mi cuento, hermanas de la vida; o amigas de mi alma; o señores de la vida. Según Correas, "Es ordinario bordoncillo en mujeres, contando algo en veladas. Otros muchos vienen comentados en parecidos términos:

Ansí pase el toro por su puerta.

Dícese esto con amor a los que se pasan de largo sin hablar con los conocidos, como quejándose de que no paren; úsanlo mucho las mujeres. (VR, 89)

Bendita sea la madre que te parió.

Dicho de mujeres alabando mucho un sermón, u otra virtud y gracia de mozo o mujer hermosa. $(\mathrm{VR}, 121)$

Buena cara tienes, buenos hechos harás.

Las gitanas lo usan decir a quien dicen la buena ventura. (VR, 133)

\footnotetext{
${ }^{32}$ Las llamadas fórmulas rutinarias se diferencian de los refranes (y otros tipos de paremias) fundamentalmente en dos aspectos: uno, que las paremias poseen significado referencial, mientras que en las fórmulas rutinarias el significado es de tipo social, expresivo o discursivo fundamentalmente. El otro es que las paremias gozan de autonomía textual, mientras que las fórmulas vienen determinadas por situaciones y circunstancias concretas; vid. Corpas (1996: 132 y 170-213) para los distintos tipos de fórmulas.
} 
Para mi santiguada. Juramento ordinario de mujeres; y es: la cara. (VR, 622)

¡Para la mi santiguada, que de donde vino el asno venga la albarda! Lo primero es juramento ordinario de mujeres, como decir: "Por mi cara santiguada". (VR, 622).

Arrastrada te veas como la culebra. Arrastrada me vea como la culebra. Dícenlo las mujeres maldiciendo o amenazando. (VR, 860)

Bonita era yo para no se lo decir (VR, 867)

Doyte la gracia de Dios. Modesta manera de reñir madres a niños. (VR, 916)

Negra cena tú tienes. Dice la madre al muchacho que se anduvo baldío. (VR, 1.006)

Lumbre de mis ojos. Dícenlo las madres a los hijos. (VR, 990)

Mi ce. A la mi fe. Mi fe. Juramentillos de mujeres. (VR, 1.001)

Ni esto. Dícese prendiendo con la uña del dedo pulgar en los dientes de la lumbre, soltando como mostrando nonada. "No le debo ni esto"; "No le costó ni esto"; o: "No dará ni esto". Mujeres usan mucho esta frase. Como: "Ni un ceotí"; “Ni un cornado". (VR, 1.007-1.008)

Noranegra. Por: "En hora negra"; frase muy usada de mujeres. (VR, 1.027)

Para las cinco horas de Dios. Es ordinario decir de mujeres desta manera, con horas, cuando las esperaron o dieron tantos reales. "Dile ocho reales, para las ocho horas de Dios"; "Esperé cinco horas, para las cinco horas de Dios". (VR, 1.035)

Parece molino. Parece aceña. Dicho de mujeres por la casa, si no está bañada en agua; que son muy amigas de barrer y regar; y más su cara. (VR, 1.036)

Por el alma que tengo en las carnes. Juramento; más ordinario de mujeres. (VR, 1.047)

Por el siglo de cuanto más quiero. Por el siglo de mi madre... de mi padre. Juramentos; más ordinarios en mujeres. (VR, 1.047)

Como nací para morir. Razón o juramento de mujeres. (VR, 879)

En Dios y en mi ánima. Juramento, más usado de mujeres. (VR, 927)

Estemacá. Por: "Estéme acá". Las madres, por desembarazarse de los muchachos chicos, los envían a una parienta o vecina con este recado: "Ve a la señora Fulana, que te dé un poco de estemacá"; con esto entienden, y detienen al muchacho embebido en algo. (VR, 953)

Hallamos además algunas locuciones ${ }^{33}$ y variantes fonéticas y léxicas que se atribuyen a mujeres, y que son casi siempre deformaciones vulgares de los dichos:

Coronilla de enero, San Sebastián primero; o Corderilla de enero... Viejas que trasoyen y no entienden mudaron la palabra "corvilla" en "coronilla" o "corderilla" de enero, que es mediado enero; y repítolo aquí para corregirlo y dejarlo en su modo. (VR, 188)

\footnotetext{
${ }^{33}$ Locuciones nominales, o compuestos sintagmáticos nominales, huso de plata, que "llaman las mujeres" al dinero con que se pagan las hilanderas (VR, 923); Es un santo ("Cuando las mujeres abonan a quien quieren", VR, 942) es una locución verbal atributiva; son locuciones comparativas: Como unas candelas. Dícenlo mujeres, denotando lindeza en cosa o persona (VR, 1.097); Como unos azúcares. Comparación de mujeres a cosas dulces (VR, 880); Un mozo como un pino de oro. Las mujeres alaban con esto hijos (VR, 1.096); etcétera. Vid. más ejemplos en Echevarría Isusquiza (2007).
} 
La Ascensión os guarde, Conde, y la Santa Trinidad. El vulgo, y más las mujeres, pronuncian "ensinción", "insinción", o "ansinción". (VR, 410)

Correas constata también algunas peculiaridades léxicas: "Maza" dicen las mujeres, por no decir "mala" (VR, 317); ¿Quécuecen las que no tienen hombre? -Malaventura con coles. "[...] y llámalo "malaventura" porque esta palabra es muy ordinaria de las doloridas" (VR, 668) ${ }^{34}$.

En suma, los testimonios de la obra de Correas abonan la idea de que el habla de las mujeres puede diferir de la de los hombres, aunque en la mayoría de los casos estemos ante diferencias sutiles, cuantitativas antes que cualitativas ${ }^{35}$. Así lo advierte nuestro gramático al notar que "úsanlo mucho" o es "más usado de mujeres" u "ordinario (de mujeres)", lo que significa hábito y frecuencia y no exclusividad, como cuando reconoce que "hombres lo usan". Adviértase que Correas se muestra sensible a las peculiaridades masculinas, como en "En Dios y en mi conciencia. Juramento, más usado de hombres" (VR, 927). Además, no siempre utiliza el hiperónimo mujer sino que especifica un subtipo que combina el género con otra variable: habla así de viejas, gitanas, brujas, sayaguesas, etc. Las mujeres en general serán las de las clases populares y de mediana edad, las que hacen los oficios de mujer, cuando se relacionan entre sí. El cómo y el porqué36 de las diferencias lingüísticas de género y de las preferencias léxicas y fraseológicas de unas y otros, son una intensa comunidad de uso femenino en los espacios comunicativos tradicionales ${ }^{37}$.

\subsection{De mujeres: refranero temático}

Los refranes de oficios o instrumentales constituyen un subtipo claramente diferenciado en el acervo paremiológico de las lenguas ${ }^{38}$. Estas paremias conciernen a trabajos prácticos y técnicos, y se vinculan a la actividad profesional de ciertos grupos

\footnotetext{
${ }^{34}$ Más ejemplos en Echevarría Isusquiza (2007).

${ }^{35}$ Pueden encontrarse buenas síntesis de los estudios sobre la sociolingüística del género en español en Blas Arroyo (2005: 160 y ss.) y Moreno Fernández (1998: 39-40).

${ }^{36}$ En la evolución de los estudios de género se ha producido una destacable desesencialización de esta categoría, que ya no se contempla como un conjunto de características estáticas, determinadas por factores que escapan al control de los individuos (biológicos o ambientales) y que son estables en los diferentes contextos. Block (2002) plantea con mucha claridad la evolución de los estudios de género y la adopción de un punto de vista contextualizado y dinámico, "sociopragmático", en palabras de Santaemilia (2002).

${ }^{37}$ Un hecho de la cultura tradicional que P. García Mouton (2003: 26) describe así: “La mujer siempre vivió en comunidad. Alrededor de ella se organizaba la familia en un espacio cerrado y, fuera de él, sus actividades eran, en general, más sociales que las del hombre, aunque limitadas a un mundo femenino. [...] Protegidas en un ambiente familiar, donde los lazos serían afectivos y la comunicación constante con los niños y los mayores, probablemente estaban más que acostumbradas a compartir sus razonamientos y a expresar afecto a través de la palabra. La conversación sería, para ellas, una forma de organizar la vida a su alrededor".

${ }^{38}$ Combet (1971: 27-48) subraya la importancia en el refranero español de los proverbios "de expresión directa" (no metafórica o figurada, por ejemplo, no dejes para mañana lo que puedas hacer hoy), a la que pertenecen precisamente los meteorológicos y agrícolas, los artesanos y todo lo que se podría calificar como proverbios-receta, los médicos e higiénicos, etc.
} 
sociales. En el Vocabulario de Correas hallamos una nutrida colección de refranes que contienen saberes prácticos, enseñanzas y reflexiones relativos a las labores típicamente femeninas de la época, la profesión de mujer; por ejemplo, el hilado, cuya conexión con el género es tan estrecha que Correas registra la fórmula A las que hilan, como "Respuesta a pullas y dichos que pican de hembra; que es: a las mujeres" (VR, 22). Lo mismo cabe decir de la fabricación del pan, y demás tareas de la economía doméstica, así como la crianza de los hijos, que son "los oficios de mujer y de casa", por usar las palabras del propio Correas:

La hija al huso, y el hijo al escudo. Dice a cuál lado están en el vientre de la madre en su preñez; y también que a la hija se enseñen los oficios de mujer y de casa, y al varón los de hombre, para servir en su república, y las armas para defender su patria. (VR, 421)

El hilado, trabajo femenino universal en la época, da lugar a numerosos refranes de sentido literal: Con escobilla el paño, y la seda con la mano. Se ha de limpiar (VR, 181); Costurera mala, la hebra de a brazada; o de a vara; o larga (VR, 190); La mazaroca a la osca, marido a la horca; la mazorca al culo, marido cornudo; la mazorca en medio, marido a concejo ${ }^{39}$; Cuando de noche se aspa, el diablo en el aspa cabalga (VR, 195), etc. ${ }^{40}$

El pan y otras tareas domésticas: La masa de la pulida, con agua y no con harina (VR, 427); A la moza que mal lava, siete veces le hierve el agua (VR, 18); Más vale rato de sol que cuarterón de jabón (VR, 506). La crianza es el asunto de Boba madre tuviste si al mes no te reíste (VR, 128); Cuando el niño dienta, la muerte le tienta (VR, 197); Cuando el niño endentece, presto hermanece. Cuando el niño endienta, presto emparienta (VR, 197); Niño que no ríe a las siete semanas, o es ruin, o tiene ruines amas (VR, 559), y otros muchos de la misma naturaleza.

Asimismo, ciertas fórmulas que condensan algunos conocimiento sobre el cuerpo femenino y salud e higiene en general, parecen destinadas específicamente al adiestramiento de mujeres: Con la hierbalán y la ruda, no se muere criatura (VR, 182); Guarte del sol de marzo, y estarás hermosa todo el año (VR, 368); Si quieres bien empreñar, guárdate de segundar (VR, 742), etc.

Todas estas recetas sobre fisiología y cuidados forman parte aún del conjunto de lecciones materiales destinadas a la esposa. Si a tu marido quieres matar, dale coles por San Juan (VR, 729) transmite un consejo sobre salud de una forma directa, así que no parece tener otro sentido que el literal. Sin embargo, los refranes técnicos o profesionales también permiten una interpretación de corte moral:
Asienta culo, y henchirás huso. Que se asista al trabajo y lucirá. (VR, 106)
El pie en la cuna, las manos en la rueca, hila tu tela y cría tu hijuela (VR, 289)
Cual hilamos, tal andamos (VR, 192)
Dueña que mucho mira, poco hila (VR, 242)

\footnotetext{
${ }^{39}$ Dice Correas que "Tiene lenguaje de la raya de Portugal en tierra de Ciudad Rodrigo, en el Abadengo. (VR, 427). Según la anotación de Combet (ibidem), es refrán de hilanderas, quizá con alusiones obscenas por el sentido figurado que solía darse al vocablo hueca.
}

${ }^{40}$ En Echevarría Isusquiza (2007) puede verse una colección de ejemplos más amplia. 
Lino ni lana no quiere solana; [o] ventana; o quintana. Destas tres maneras le acaban, y es todo uno, porque con la humedad despide mejor la hebra; también quiere atentas y no embebidas en mirar, y con este sentido se aplica a otras cosas y oficios. (VR, 460)

Y de aquí se pasa a Lino y marido, nunca es escogido (VR, 460), en el que el lino es un mero pretexto.

\subsection{De mujeres: educación, definición y defensa}

Pero también es este un refrán "de mujeres", porque son "de mujeres" aquellos que les están dirigidos, más aún porque son ellas mismas las que se instruyen entre sí. Lo cual ocurre tanto en el caso de los saberes prácticos como en los de índole moral que tienen que ver con la educación, definición y también defensa de las mujeres, por ellas mismas. Está claro que son unas las que aconsejan a otras acerca de cómo actuar con el marido:

Sírvele como a marido, y guarte dél como de enemigo. Consejo a la casada. (VR, 751)

Al marido, ámale como a amigo, y témele como a enemigo $(\mathrm{VR}, 61)$

Al marido, sírvele como a señor, y guárdate dél como de un traidor (VR, 61)

Comé con él y guárdate dél. Aviso a la mujer casada con su marido (VR, 168)

Tan buen bofetón da el marido malo, como el bueno y honrado (VR, 763)

Tan gran bofetón da, y tan recio, el marido malo como el bueno (VR, 763)

A tu esposo, muéstrale [palabra borrada] mas no del todo. A tu esposo, muéstrale el có, mas no del tó. A tu marido, muéstrale el codo, mas no del todo (VR, 38)

A tu marido, muéstrale lo otro, mas no del todo (VR, 38)

Ni calentura con frío, ni marido en casa contino $(\mathrm{VR}, 546)$

El testimonio concordante de Correas confirma de nuevo nuestra apreciación:

Al marido malo, ceballo con gallinas de a par del gallo. Reprehenden otras mujeres en esto a la que regala al marido que no lo merece. Las gallinas de a par del gallo en el gallinero siempre son las más gordas. Otro sentido es: que se le hagan caricias para salir la mujer con lo que quiere, conforme al de arriba: "...cegallo...". Más caritativo fuera que al marido malo, enfermo, se le cebara y le regalara. Truécanse también las dos primeras palabras: "Al mal marido, cegallo...; o ceballo..." (VR, 61).

A la hija, tápala la rendrija. Que la quites las ocasiones de tu casa, y no la des mal ejemplo en que vea lo que haces con tu marido. "Rendrija" es: abertura para ver, y poderse comunicar con quien gustare". (VR, 17)

$\mathrm{Ni}$ todos los refranes que contienen consejos y avisos para las mujeres podrían ser considerados de mujeres, ni mucho menos lo serán aquellos que hablan de ellas y las definen, entre los que se encuentran, precisamente, los que más odio y desprecio destilan. Por ejemplo, "En mujeres, y ciegos, y frailes, los mosquitos son elefantes. Que por poco que sepan y hagan, son muy alabados" (VR, 352), no parece típicamente dicho por mujer (ni por ciego ni por fraile).

Sin embargo, hemos de reconocer que hay una serie de refranes dirigidos a mujeres, y que van de los muy prácticos a los más espirituales, que sí piden por defecto un contexto de transmisión que es la educación de mujeres por las propias mujeres. 
Consejos de belleza, como Guarte del sol de marzo, y estarás hermosa todo el año (VR, 368); de economía doméstica: "Ni tu lino en tocas, ni tu pan en tortas. Porque lo que está en menudencias vase de entre las manos sin sentir" (VR, 556). O sobre amores: Hombre besador, poco empreñador, que según Correas, es refrán que "inventaron las mujeres" $(\mathrm{VR}, 394)$.

Y también resulta lógico suponer que las mujeres se defienden a sí mismas de la misoginia con el elogio y encarecimiento de sus cualidades y del valor del papel que desempeñan en la sociedad:

Donde hay mujeres, hay modo (VR, 238)

A quien buena mujer tiene, ningún mal le puede venir que no sea de sufrir (VR, 31)

Dichos de viejas arrancan las piedras $(\mathrm{VR}, 226)$

El consejo de la mujer es poco, y el que no le toma es loco (VR, 262)

Y con ironía, especialmente reconfortantes resultan los que contestan a la machacona prescripción de que la mujer (más que el hombre) no sea ociosa:

Cogombros y agua de la noria, ¿de qué te quejas, señora?; [o] mujer? (VR, 167)

Puta, y pobre, y buena mujer, no puede ser (VR, 666)

Come, y duerme, y engorda; si te llamaren hazte sorda $(\mathrm{VR}, 169)$

La que mucho hizo se muere, y la que poco, tambiene $(\mathrm{VR}, 442)^{41}$

Llegados a este punto, que es el final, vemos recorrido el camino que lleva de la escenificación del estereotipo de las conductas y palabras femeninas, vehículo para transmitir múltiples enseñanzas, a la educación de mujeres a través de la transmisión oral de saberes prácticos y de consejos morales. En este ámbito he querido destacar el interés de la fraseología de mujeres (y entiéndase el complemento como genitivo subjetivo), tal y como se deduce de los usos lingüísticos que corresponden al desempeño de sus cometidos sociales, y teniendo siempre presente la forma en que el propio Correas reparaba en ella. Constatamos que el refranero puede ser contemplado a luz de distinciones que, como el género, permiten reconocer a algunos de sus sujetos, nombrar las voces de la multitud anónima que forma la comunidad lingüística.

\section{BIBLIOGRAFÍA}

Abascal, M.D. (2004): La teoría de la oralidad, Málaga, Analecta Malacitana-Universidad de Málaga.

Almela Pérez, R. y J. Sevilla Muñoz, (2000): “Paremiología contrastiva: propuesta de análisis lingüístico", Revista de Investigación Lingüística, 1: 7-47.

Ambadiang, Th. (1999): “La flexión nominal. Género y número", en I. Bosque y V. Demonte (Eds.) (1999): Gramática descriptiva de la Lengua Española, Madrid, RAE / Espasa Calpe, III: 4843-4914.

\footnotetext{
${ }^{41}$ Creo que la forma cabal de este refrán es la inversa: "La que poco hizo se muere y la que mucho tambiene", pues es así como cobra sentido el tópico de la muerte igualadora.
} 
Arnaud, P.J.-L. (1991): “Réflexions sur le porverbe”, Cahiers de Lexicologie, 59: 5-27.

Blas Arroyo, J.L., (2005): Sociolingüística del español. Desarrollos y perspectiva en el estudio de la lengua en contexto social, Madrid, Cátedra.

Block, D., (2002): “Language and gender and SLA", en J. Santaemilia Ruiz et alii (Eds.), Sexe i llenguatge: la construcció lingüística de les identitats de gènere. Quaderns de Filología. Estudis Lingüístics, VII: 25-46, Valencia, Universidad de Valencia.

Bravo, F. (1992): "La négation antiphonique en espagnol. La formule de renforcement "ni ínsulas ni ínsulos": Étude synchronique et diachronique", Bulletin Hispanique, 94: 619-672.

Calero Fernández, Ma Á. (1991): La imagen de la mujer a través de la tradición paremiológica española (lengua y cultura), Barcelona, Publicaciones Universitat de Barcelona, Tesis doctoral microfichada.

Calero Fernández, Ma Á. (1992): “Nombres parlantes femeninos en la onomástica paremiológica española", en M. Ariza et alii (Eds.) (1992): Actas del II CIHLE (Sevilla, 1991), Madrid, Arco, II: 907-918.

Chevalier, M. (1978): Folklore y Literatura. El cuento oral en el Siglo de Oro, Barcelona, Crítica.

Combet, L. (1971): Recherches sur le «refranero» castillan, París, Les Belles Lettres.

Combet, L. ([1967] 2000): «Prólogo de la edición de 1967», de Correas, G. ([1967] 2000): XV-XXXIII.

Corpas Pastor, G. (1996): Manual de fraseología española, Madrid: Gredos.

Correas, G. ([1967] 2000): Vocabulario de refranes y frases proverbiales, texto establecido, anotado y presentado por Louis Combet, Burdeos, Instituto de Estudios Ibéricos e Iberoamericanos de la Universidad de Burdeos, 1967. Edición de Louis Combet, revisada por Robert Jammes y Maïte Mir-Andreu, Madrid, Castalia.

Coseriu, E. (1981): “Introducción al estudio estructural del léxico", Principios de semántica estructural, Madrid, Gredos, $2^{a}$ ed., 87-142.

Covarrubias y Orozco, S. de ([1612] 1943): Tesoro de la Lengua Castellana o Española, Madrid, Luis Sánchez; ed. de Martín de Riquer, Barcelona, S.A. Horta (con las adiciones de Benito Remigio Noydens a la edición de 1673-1674).

Cruse, D.A. (2000): Meaning in Language. An Introduction to Semantics and Pargmatics, Oxford, Oxford University Press.

De La Rosa, J. (1993): “La misoginia de refranes y frases proverbiales en los relatos trágicos del siglo XVII en Francia y en España”, Paremia, 2: 199-204.

Echevarría Isusquiza, I. (2007): “Refranes y frases de mujeres en el Vocabulario de Correas", Conde Tarrío, G. (Dir.), El componente etnolingüístico de la Paremiología. The ethnolinguistic Copmponent of Paremiology, Editions Modulaires Européenes (E.M.E.), Fernelmont (Belgique), 86-116. 
Echevarría Isusquiza, I. y Arbulu Aguirre, J. (2008): “Apuntes sobre fraseología y literatura", Cadernos de Fraseoloxía Galega, 10: 79-94.

Frenk Alatorre, M. (1965): “Refranes cantados y cantares proverbializados", NRFH, 15: 155-168.

Frenk Alatorre, M. (1997): “La compleja relación entre refranes y cantares antiguos”, I Congreso Internacional de Paremiología. Paremia, 6: 235-244.

Frenk Alatorre, M. (ed.) (2004): Lírica española de tipo popular. Edad Media y Renacimiento, Madrid: Cátedra, $13^{\mathrm{a}}$ ed.

García Murga, F. (2002): El significado, Muenchen, Lincom Europea.

García Mouton, P. (2003): Así hablan las mujeres. Curiosidades y tópicos del uso femenino del lenguaje, Madrid, La Esfera de los Libros.

Jammes, R. (2000): “Presentación” de Correas, G. ([1967] 2000): IX-XIII.

Lázaro Carreter, F. (1980a): “Literatura y folklore: los refranes”, en Estudios de lingüística, Barcelona, Crítica: 207-217.

Lázaro Carreter, F. (1980b): “La lengua de los refranes, ¿espontaneidad o artificio?” en Estudios de lingüística, Barcelona, Crítica: 219-232.

Lyons, J. (1980): Semántica, Barcelona, Teide.

Menéndez Pidal, R. (1982): "Proemio" de Flor nueva de romances viejos, Madrid, EspasaCalpe, $5^{\mathrm{a}}$ ed.

Moreno Fernández, F. (1998): Principios de sociolingüística y sociología del lenguaje, Barcelona, Ariel.

Pena Seijas, J. (1999): "Partes de la morfología. Las unidades del análisis morfológico", en I. Bosque y V. Demonte (eds.), Gramática descriptiva de la Lengua Española, Madrid: RAE / Espasa Calpe, III: 4305-4366.

Real Academia Española ([1726-1739] 1992): Diccionario de la lengua castellana, en que se explica el verdadero sentido de las vozes, su naturaleza y calidad, con las phrases o modos de hablar, los proverbios o refranes, y otras cosas convenientes al uso de la lengua, Madrid, Imprenta de Francisco del Hierro, Impresor de la RAE, 6 tomos. Edición facsímil, Diccionario de Autoridades, Madrid, Gredos, 3 vols.

Rosal, F. del ([1601] 1992]: Origen y etymología de todos los vocablos originales de la lengua castellana (1601, Ms. 6929 - t 127 de la Biblioteca Nacional: Diccionario etimológico: Alfabeto primero de Origen y etymología de todos los vocablos originales de la Lengua Castellana), ed. facsimilar y estudio de Enrique Gómez Aguado, Madrid, CSIC.

Rosal, F. del ([1601] 1976]: Alfabeto tercero. La razón de algunos refranes, ed. de B. Russell Thompson, Londres, Tamesis.

Santaemilia Ruiz, J. (2002): “Towards a pragmatics of gendered conversation: a few general considerations", en J. Santaemilia Ruiz et alii (Eds.), Sexe i llenguatge: la construcció lingüística de les identitats de gènere. Quaderns de Filología. Estudis Lingüístics, VII: 93-113, Valencia, Universidad de Valencia. 
Schapira, Ch. (1999): Les stéréotypes en français. Proverbes et autres formules, París, Ophrys. Tarnovska, O. (2000): «Refranes machistas ucranianos y españoles», en AADD, Trabajos de lexicografía y fraseología contrastivas, Granada, Método.

Venier, M.E. (1985): “Como el asno, la mujer. De paremiología femenina”, Diálogos (El Colegio de México), 21-124: 28-31.

Violi, P. (1991): El infinito singular, Madrid, Cátedra. 